\title{
Lessons and Limits of Mouse Models
}

\author{
Anita S. Chong ${ }^{1}$, Maria-Luisa Alegre ${ }^{2}$, Michelle L. Miller ${ }^{2}$, and Robert L. Fairchild ${ }^{3}$ \\ ${ }^{1}$ Section of Transplantation, Department of Surgery, The University of Chicago, Chicago, Illinois 60637 \\ ${ }^{2}$ Section of Rheumatology, Department of Medicine, The University of Chicago, Chicago, Illinois 60637 \\ ${ }^{3}$ Department of Immunology, Lerner Research Institute, The Cleveland Clinic, Cleveland, Ohio 44195 \\ Correspondence: achong@uchicago.edu
}

Seminal studies in rabbits and rodent transplantation models by Peter Medawar revealed that cellular processes, rather than humoral antibodies, are central to the acute rejection of transplanted organs, and much of basic transplantation research continues to be focused on the biology and control of these cells, which were subsequently shown to be T cells. However, the success of current immunosuppression at controlling T-cell-mediated rejection has resulted in an increasing awareness of antibody-mediated rejection in the clinic. This, in turn, has fueled an emerging interest in the biology of allospecific antibodies, the $\mathrm{B}$ cells that produce these antibodies, and the development of mouse models that allow their investigation. Here we summarize some of the more widely used mouse models that have been developed to study the immunobiology of alloreactivity, transplantation rejection and tolerance, and used to identify therapeutic strategies that modulate these events.

$\mathrm{R}^{\mathrm{o}}$ odent models in transplantation have been essential to developing a mechanistic understanding of the process of allograft rejection, as well as to the identification of novel therapeutic approaches that prevent rejection. Models of transplantation tolerance in mice and other rodents have paved the way to translational studies of tolerance induction in nonhuman primates and humans, whereas the failures in translating the successes in tolerance induction observed in mice into the clinic have led to a closer examination of the limitations of the mouse models and the identification of physiological barriers to tolerance induction.

\section{ORGAN-SPECIFIC MODELS OF ACUTE REJECTION}

Clinicians have long appreciated the importance of the organ type in shaping the alloreactive immune response, with lungs and small intestines having a higher propensity to being rejected compared with hearts, kidneys, or livers. Early models of organ transplantation were limited by microsurgical techniques, and the skin transplant model was extensively used. With technical advances, the heterotopic heart transplantation model is now the model of choice, although other organ transplantation models, such as kidney or liver, offer unique advantages (see Fig. 1).

Editors: Laurence A. Turka and Kathryn J. Wood

Additional Perspectives on Transplantation available at www.perspectivesinmedicine.org

Copyright (C) 2013 Cold Spring Harbor Laboratory Press; all rights reserved; doi: 10.1101/cshperspect.a015495

Cite this article as Cold Spring Harb Perspect Med 2013;3:a015495 


\section{A.S. Chong et al.}

\section{Skin Transplantation}

Following the unsuccessful efforts to use skin transplants to replace burned or damaged skin on injured British airmen and soldiers during World War II, Peter Medawar's experiments with rodent models of skin transplantation revealed fundamental rules of the acceptance of autologous and the rejection of heterologous skin grafts (Gibson and Medawar 1943; Medawar 1944, 1945; Billingham and Medawar 1951; Steinmuller 1984). The availability of genetically defined strains of mice has led to the understanding that complete major histocompatibility complex (MHC)-mismatched or even single class I or class II MHC mismatched skin allografts are quickly recognized by the recipient $\mathrm{T}$ cells and rejected. In contrast, rejection of $\mathrm{MHC}$ matched/multiple (e.g., BALB.B $\rightarrow$ BALB/c) or (male $\rightarrow$ female) minor histocompatibility antigen-mismatched allografts can take a considerable amount of time to be rejected and may not be rejected at all.
A

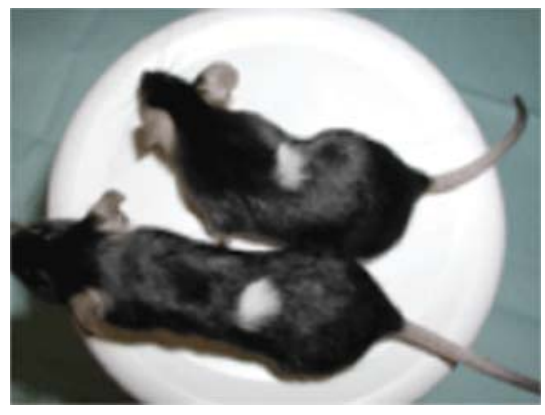

C

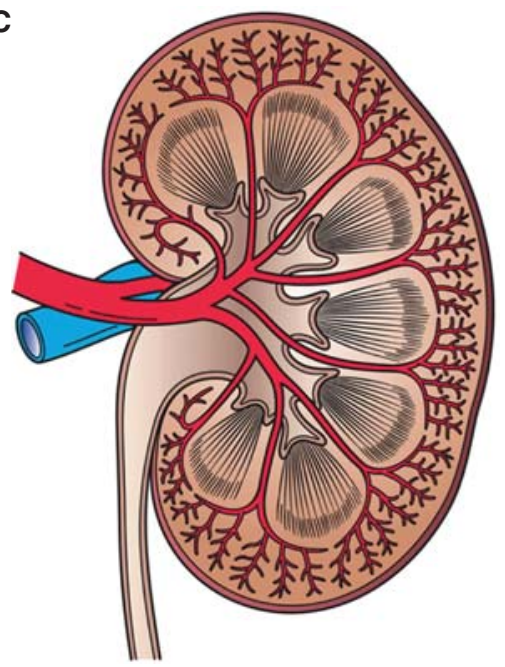

B

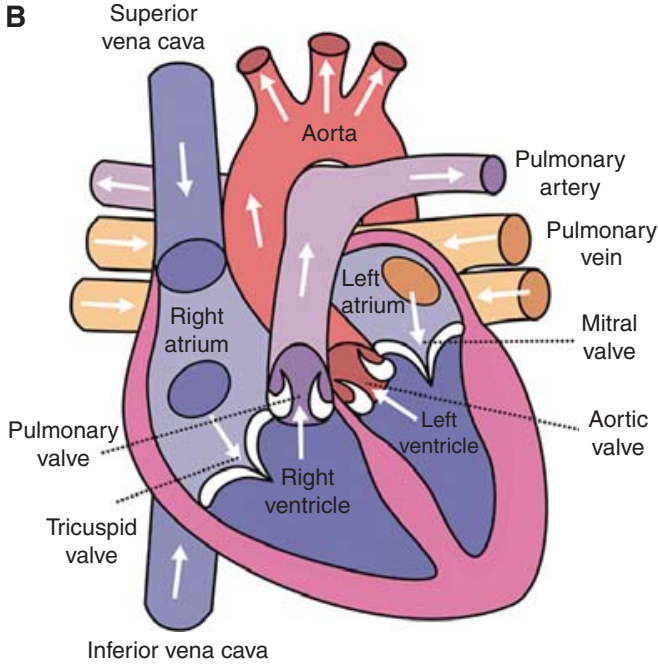

D

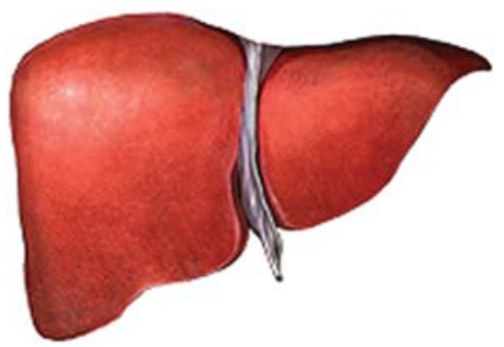

Figure 1. (A) Skin transplantation: Technically simple, a good model for acute T-cell-mediated rejection, and considered a stringent model of tolerance. $(B)$ Heterotopic heart transplantation: Moderate technical difficulty, a good model for acute T-cell-mediated rejection, can model acute and chronic antibody-mediated rejection, notable differences in the pathology of chronic rejection from human chronic rejection, and most common model to investigate immunological tolerance. $(C)$ Orthotopic kidney transplantation: Technically difficult, can be a life-sustaining graft, and can model spontaneous graft acceptance and chronic rejection. $(D)$ Orthotopic liver transplantation: Technically very difficult, life-sustaining graft, and clinically relevant model of spontaneous graft acceptance. 
The procedure for skin transplantation developed by Medawar and colleagues involves the removal of the abdominal skin from the donor and placement on the prepared graft bed in the recipient where the skin graft is wrapped. It takes $48-72 \mathrm{~h}$ for the graft to become revascularized by vascular endothelium growing from the recipient bed into the graft (Capla et al. 2006; Lindenblatt et al. 2008; Calcagni et al. 2011). This need for revascularization can impact the alloimmune response to the graft because the longer period of ischemia until revascularization occurs influences the inflammatory state within the skin allograft and therefore the function of the graft-derived antigen-presenting cells (APCs). These APCs have immediate access, through lymphatic drainage, to recipient secondary lymphoid organs where they stimulate donor-reactive $\mathrm{T}$ cells. Vascularization of skin allografts has also been shown to impact the early transmigration of donor T cells into the draining lymph nodes that then alter the specificity, tempo, and/or intensity of the alloreactive response by recipient T cells (Kwun et al. 2011). In contrast, host leukocytes including memory $\mathrm{CD}^{+} \mathrm{T}$ cells may have early access to the allograft endothelium to promote early inflammation and subsequent rejection (Schenk et al. $2008,2009)$. There is an additional nuance to the skin transplant model, particularly when only minor histocompatibility differences are involved and trunk skin allografts are eventually rejected, whereas tail skin allografts are not (McFarland and Rosenberg 2009). This differential susceptibility to rejection has been proposed to be due to the density of epidermal dendritic cells (DC) (i.e., Langerhans cells) and dermal dendritic cell populations, which is much higher in trunk skin versus tail skin (Bergstresser et al. 1980a,b; Chen and Silvers 1983). Thus, the trunk skin allograft model is considered a more robust model of rejection compared with the tail skin.

\section{Heterotopic Heart Transplantation}

The vascularized, intra-abdominal, heterotopic heart graft model in which the graft is transplanted into the recipient peritoneal cavity of a mouse was developed by Corry et al. (1973). The surgical procedure involves end-to-end anastomosis of the heart graft aorta to the recipient abdominal aorta and the graft pulmonary artery to the recipient inferior vena cava. Upon completion of the anastomosis, the heart graft quickly begins contracting. The advantages of this model are the immediate vascularization and the ease of monitoring rejection by palpating the heartbeat of the graft; thus, this is an excellent model to study alloreactivity that results in acute rejection. The shortcomings of the model are that it is a nonfunctional graft that does not pump blood despite heart graft contractions, and there is marked epicardial and endocardial inflammation due to chronic ischemia from abnormal blood flow. The absence of functional contraction results in progressive atrophy of the transplanted graft while the inflammatory response impinges on coronary arteries that are located near the epicardium and endocardium, especially on the right free wall and septum.

When complete MHC-disparate (e.g., both class I and class II MHC allelic differences) heart allografts are heterotopically transplanted into immunocompetent recipients, they are rejected (defined as the complete cessation of heartbeat) within 7-10 d (Corry et al. 1973; Schenk et al. 2008, 2009; Kwun et al. 2011). Characteristics of this rejection are similar to acute cell-mediated rejection in clinical transplantation, namely, an intense mononuclear cell infiltrate that includes macrophages and $\mathrm{T}$ cells, with $\mathrm{CD}^{+} \mathrm{T}$ cells predominating over $\mathrm{CD}^{+}{ }^{+} \mathrm{T}$ cells. Transplant of single class I MHC- or class II MHC-mismatched heart allografts or MHC-matched/ multiple minor mismatched allografts generally does not provoke acute rejection, and these grafts can survive for $>60-80 \mathrm{~d}$ (Schenk et al. 2005; Hattori et al. 2012). A major reason for the lack of acute rejection is postulated to be the low frequency of donor-reactive $\mathrm{T}$ cells that permits the dominance of regulation over this response (Schenk et al. 2005). Studies by He et al. (2004) indicated that the size of the allograft is also an important factor in determining allograft outcome. For example, female recipients do not normally reject MHC-matched, minor antigen-disparate male heart allografts from adult, large-size donors but will reject smaller 
A.S. Chong et al.

hearts from young (e.g., 3-wk-old) donors, suggesting that rejection can be affected by the graft itself, in addition to the immunological response it elicits.

Because the primary donor-specific lymphocytes infiltrating MHC-mismatched cardiac allografts are $\mathrm{CD} 8^{+} \mathrm{T}$ cells, the role of $\mathrm{CD} 4^{+} \mathrm{T}$ cells in mediating acute cell-mediated rejection has been investigated with allografts that have only class II MHC disparity. B6.H-2 $2^{\mathrm{bm} 12}$ is a spontaneous mutation resulting in a three-amino-acid change in the third hypervariable region of the $\beta$-chain of the class II I- $\mathrm{A}^{\mathrm{b}}$ molecule (McKenzie et al. 1979; Mengle-Gaw et al. 1984). B6.H-2 ${ }^{\text {bm12 }}$ skin grafts are acutely rejected by C57BL/ 6 recipients as a result of the priming of I-A ${ }^{\text {bm12 }}$ reactive CD4 T cells (Yun et al. 2002; Schenk et al. 2005). The heart allografts are not acutely rejected but develop an occlusive vasculopathy that is also dependent on I-A ${ }^{\mathrm{bm} 12}$ reactive CD4 T cells. The explanation for heart allograft acceptance is that the skin is more immunogenic than the heart, and the anti-I-A ${ }^{\text {bm12 }}$ response is highly regulated as a result of $\mathrm{I}-\mathrm{A}^{\mathrm{bm} 12}$ being so similar to $\mathrm{I}-\mathrm{A}^{\mathrm{b}}$ (Lafuse et al. 1981). Indeed, the removal of $\mathrm{CD}^{+}$ $\mathrm{CD} 25^{+}$T-regulatory cells results in an increased donor-reactive CD4 T-cell response and acute rejection of the I-A ${ }^{\text {bm12 }}$ heart allografts (Schenk et al. 2005). Thus, several investigators have used the $\mathrm{B} 6 . \mathrm{H}-2^{\mathrm{bm} 12} \rightarrow \mathrm{C} 57 \mathrm{BL} / 6$ heart allograft model to study regulatory $\mathrm{T}$-cell function as well as the development of allograft vasculopathy. Caveats of this model to study the pathogenesis of chronic rejection have been raised because the occlusive vasculopathy that develops in clinical heart transplants looks very different from that developing in the $\mathrm{B} 6 . \mathrm{H}-2^{\mathrm{bm} 12}$ heart allografts.

There has been increasing discussion regarding the appropriate use of mouse heart transplant models to model clinical chronic rejection pathologies, including the anatomical and surgical differences with the human transplant model as discussed above, and the fact that immunosuppression in these models is often limited to subclinical levels of one agent, or that no immunosuppression is used when transplants are performed between weakly in- compatible strains. As a result, most experimental heterotopic heart transplants incur acute rejection grades that are no longer observed in the clinic. In these murine models, acute interstitial inflammation resolves into a prominent interstitial fibrosis that is not typical of chronic rejection in human heart transplants. Suboptimal immunosuppression also results in a much greater acute vascular injury, resulting in the injured donor endothelial cells and smooth muscle cells being replaced by cells of recipient origin (Krasinskas et al. 2000); the most extreme example of donor cell replacement being observed with interpositional segmental aorta grafts in mice and rats that undergo complete intimal denudation and replacement by adjacent endothelium (Hagensen et al. 2011). Although the published data in human heart transplants are not in complete agreement, the more recent reports indicate that the majority of cells are of graft origin even years after transplantation (Atkinson et al. 2004; Minami et al. 2005). Another important difference between humans and mice is the anatomical location of the coronary arteries. Human coronaries are located on the epicardium, and chronic allograft vasculopathy in humans develops primarily in the epicardial portions of the coronary arteries with limited involvement of intramural branches (Lu et al. 2011). In contrast, rodent coronary arteries are largely intramural, and the pathological lesion found in intramural coronary branches is often characterized by medial necrosis and fibrosis. The most severe arterial pathology in murine cardiac allografts is usually found in the small epicardial segment of the coronary artery close to the aortic root (Wehner and Baldwin 2010). These differences may impact the clinical relevance of mechanistic studies of immune-mediated pathology and rejection of murine grafts, and thus caution has to be exercised.

\section{Kidney Transplantation}

An ideal solid organ transplant model is one that functions to support the life of the recipient-the raison d'être for clinical transplantation. Thus, in contrast to heterotopic heart transplants, renal transplantation can be per- 
formed in nephrectomized mice so that the viability of the recipient is dependent on the function of the graft. The kidney graft is harvested en bloc with the ureter so that the transplant surgery involves revascularization of the kidney graft and connection of the donor ureter to the recipient bladder, either through insertion of the ureter into the bladder or through generation of a bladder patch (Ge and Gong 2011). The function of the graft in nephrectomized recipients is assessed by the quantification of serum creatinine, similar to clinical renal transplantation.

Acute rejection of complete MHC-mismatched kidney allografts is observed in some mouse recipient $\rightarrow$ donor strain combinations, including $\mathrm{C} 57 \mathrm{BL} / 6 \rightarrow(\mathrm{C} 3 \mathrm{H} \times \mathrm{DBA} / 2) \mathrm{F}_{1}$ (Skoskiewicz et al. 1973) and $\mathrm{C} 57 \mathrm{BL} / 6\left(\mathrm{H}-2^{\mathrm{d}}\right) \rightarrow$ $\mathrm{BALB} / \mathrm{c}\left(\mathrm{H}-2^{\mathrm{d}}\right)$ or $\rightarrow \mathrm{B} 10 . \mathrm{BR}\left(\mathrm{H}-2^{\mathrm{k}}\right)$ recipients (Pratt et al. 2002; Li et al. 2010). In other combinations, such as BALB $/ \mathrm{c} \rightarrow \mathrm{C} 57 \mathrm{BL} / 6$, renal allografts are slowly rejected, with $60 \%$ rejecting between day 12 and 50 posttransplant and the other $40 \%$ surviving long-term (>100 d) (Meng et al. 2008; Wu et al. 2012). Thus, the kidney transplant model provides a model for studying alloimmune responses and the pathology of acute and chronic graft rejection that is potentially more clinically accurate. However, it is considerably more technically demanding to perform the surgery and to monitor rejection compared with the skin and heterotopic heart model, thus limiting deeply mechanistic studies.

\section{MODELS OF B-CELL AND ANTIBODY- MEDIATED REJECTION}

Studies defining the role of $B$ cells in transplantation have focused on the effects of alloantibodies secreted by plasma cells arising from the terminal differentiation of alloreactive B cells (summarized in Table 1). Antibodies can cause hyperacute (HAR), acute, and chronic antibody-mediated rejection (AMR); however, routine preoperative serological testing for preformed antihuman leucocyte antigen (HLA) and anti-ABO antibodies has reduced HAR to a rare clinical occurrence, whereas antibodymediated acute or chronic rejection has emerged as a pressing problem in clinical transplantation (for review, see Mengel et al. 2012; Smith and

Table 1. Adoptive transfer of antibodies into B-cell or T- and B-cell (Rag)-deficient recipients to investigate antibody-mediated rejection and graft accommodation

\begin{tabular}{|c|c|c|c|}
\hline Rejection type & Model & Passive transfer & References \\
\hline \multirow[t]{2}{*}{ Hyperacute } & $\begin{array}{l}\text { Xenografts in Rag-deficient } \\
\text { recipients }\end{array}$ & $\begin{array}{l}\text { High-titer antibodies or low- } \\
\text { titer Abs + DAF deficiency }\end{array}$ & $\begin{array}{l}\text { Shimizu et al. 2006; Ding } \\
\text { et al. 2008a }\end{array}$ \\
\hline & $\begin{array}{l}\text { Allografts in Rag-deficient } \\
\text { recipients }\end{array}$ & $\begin{array}{l}\text { High-titer antibodies }+ \\
\quad \text { xenogeneic complement }\end{array}$ & Koene et al. 1973 \\
\hline \multirow[t]{2}{*}{$\begin{array}{l}\text { Acute, antibody } \\
\text { mediated }\end{array}$} & $\begin{array}{l}\text { Allografts in B-cell-deficient } \\
\text { recipients }\end{array}$ & $\begin{array}{l}\text { Delayed transfer of anti-MHC } \\
\text { class I mAbs }\end{array}$ & Wasowska et al. 2001 \\
\hline & $\begin{array}{l}\text { Allografts in Rag-deficient } \\
\text { recipients }\end{array}$ & $\begin{array}{l}\text { High-titer polyclonal } \\
\text { antibodies from sensitized } \\
\text { CCR5-deficient recipients }\end{array}$ & Nozaki et al. 2007 \\
\hline \multirow[t]{2}{*}{$\begin{array}{l}\text { Chronic, antibody } \\
\text { mediated }\end{array}$} & $\begin{array}{l}\text { MHC-mismatched heart } \\
\text { allograft }\end{array}$ & $\begin{array}{l}\text { Repeated transfer of anti-MHC } \\
\text { class I antibodies }\end{array}$ & Akiyoshi et al. 2012 \\
\hline & Native lung & $\begin{array}{l}\text { Repeated intrabronchial } \\
\text { transfer of anti-MHC class I } \\
\text { Abs }\end{array}$ & Fukami et al. 2009, 2012a \\
\hline \multirow[t]{2}{*}{ Accommodation } & Xenogeneic & $\begin{array}{l}\text { Repeated transfer of anti-Gal } \\
\text { antibodies }\end{array}$ & Ding et al. 2008b \\
\hline & $\begin{array}{l}\text { Single HLA-A2 mismatch } \\
\text { heart allograft }\end{array}$ & $\begin{array}{l}\text { Anti-HLA-A } 2 \mathrm{mAb} \text { transferred } \\
\text { into donor } 2 \mathrm{~d} \text { before } \\
\text { transplantation }\end{array}$ & Fukami et al. 2012b \\
\hline
\end{tabular}


A.S. Chong et al.

Colvin 2012; Stegall et al. 2012). There is, therefore, a need to better predict outcomes based on circulating donor-specific antibody titers (DSA) and analysis of biopsies, and for treatments that prevent as well as resolve ongoing antibody production and antibody-mediated rejection.

\section{Hyperacute Rejection}

It is difficult to achieve HAR of vascularized allografts in mice even in the presence of high-titer DSA. HAR is classically dependent on complement activation, and some mouse strains have complete deficiencies of C5 (A/J, AKR, B10D2, and DBA/2), low levels of C3 (B10.D2, C57BL/ 10 , and DBA.2), or $\mathrm{C} 4(\mathrm{CBA} / \mathrm{J}$ and $\mathrm{C} 3 \mathrm{H})$ that make them inappropriate for modeling HAR (for review, see Baldwin et al. 2010). In addition, a large family of complement-regulatory proteins (for review, see Morgan 1995) inhibits complement activation at different steps in the complement cascade and participates in the rapid clearance of active complement components from the cell surface, thereby protecting cells from damage. Indeed, Shimizu et al. (2006) reported that allografts lacking the complement regulator decay-accelerating factor (DAF) were susceptible to HAR in the presence of lowtiter anti- $\alpha 1,3 \mathrm{Gal}$ (Gal $\alpha 1-3 \mathrm{Gal} \beta 1-[3] 4 \mathrm{GlcNAc}$ $[\mathrm{Gal}])$ antibodies, whereas wild-type grafts were not.

HAR in mice can be induced by the passive transfer of xenogeneic rabbit complement (Koene et al. 1973) or by the transplantation of xenogeneic grafts, the rationale for the latter being that the efficacy of complement-regulatory proteins controlling complement is reduced when they have to control the activation of complement from a different species. Using a xenogeneic model of rat hearts transplanted into recombination-activating gene (Rag) ${ }^{-/-} \mathrm{Gal}^{-/-}$ mice, passive transfer of anti-Gal immunoglobulin $\mathrm{G}$ isotype (IgG3), an IgG subclass that strongly activates complement, elicited HAR in a complement-dependent manner (Ding et al. 2008a). However, monoclonal antibodies (mAbs) bearing identical antigen specificity but class switched to IgG1, IgG2a, and IgG2b subclasses that also engage $\mathrm{IgC} \mathrm{Fc}$ receptors
(Fc $\gamma$ Rs), HAR was shown to be dependent on complement activation as well as FcyRs and NK cells (Ding et al. 2008a). Those observations expanded our understanding of how HAR may be induced in vivo from a process that is only complement dependent to one in which FcyRexpressing cells also play essential roles.

\section{Acute Antibody-Mediated Rejection}

Seminal observations by Wasowska et al. (2001) showing that the adoptive transfer of allospecific mAbs in B-cell-deficient mice was able to restore acute cardiac rejection underscored the ability of alloantibodies to promote acute Tcell-mediated rejection. They went on to show that complement-fixing antibodies were most effective at promoting acute rejection, but that non-complement-fixing antibodies stimulated endothelial cell activation and synergized with complement-fixing antibodies to cause acute rejection (Rahimi et al. 2004). However, in those experiments, although antibodies were necessary, T cells were also important, resulting in a model of mixed antibody- and T-cell-mediated rejection.

The successful induction of pure acute antibody-mediated rejection in the absence of $\mathrm{T}$ cells and B cells was reported by Nozaki et al. (2007), following the adoptive transfer of sera containing extremely high-titer alloantibodies into $\mathrm{Rag}^{-/-}$recipients. For yet-to-be-defined reasons, the $\mathrm{CCR} 5^{-/-}$mice transplanted with allogeneic allografts generate extremely high titers of donor-specific antibodies that were 20 fold higher than in wild-type recipients. Acute antibody-mediated rejection was observed within $12 \mathrm{~d}$ of passive transfer of sera from sensitized CCR $5^{-/-}$but not wild-type recipients, with histological features of neutrophil and macrophage infiltration that are characteristic of acute antibody-mediated rejection. Their studies showed the importance of extremely high titers of antibodies for eliciting antibodymediated rejection in $\mathrm{Rag}^{-/-}$mice.

Although much of the focus has been on antibody interaction with graft endothelium during acute rejection, antibodies can also play an important role in the generation of op- 
sonins. Opsonins allow antigen to be presented simultaneously with bound antibodies that engage FcR and activated complement components that engage complement receptors on APCs. The engagement of these receptors promotes the up-regulation of costimulatory molecules on, and the production of cytokines by APCs, which are necessary for T-cell activation. Indeed, Burns and Chong (2011) provided experimental evidence for such opsonic activity of adoptively transferred anti-MHC class I monoclonal antibodies (mAbs). In that experimental model, recipients receiving anti-CD154 plus donor spleen cells accepted allogeneic skin long term, but in the presence of transferred antidonor $K_{d}$ mAbs, the grafts were acutely rejected, even when only the donor spleen cells, but not the skin graft, expressed $K_{d}$. These observations provided support for an alternative way in which antibodies promote cellular rejection in the absence of C4d deposition in the graft.

\section{Antibody-Mediated Chronic Rejection}

Improved assessment of DSA and C4d deposition in the allograft has strengthened the association of alloantibodies with chronic rejection and poor graft survival in the clinic. Pathological markers of chronic AMR are specific for each organ-in renal allografts, it is characterized by transplant glomerulopathy (duplication and laminations of the glomerular basement membrane) and excess laminations of the peritubular capillaries (for review, see Smith and Colvin 2012); in cardiac allografts, the hallmark of transplantation-associated arteriosclerosis is concentric vascular intimal thickening seen in chronically rejecting cardiac allografts (for review, see Soleimani et al. 2006); and in lung allografts, obliterative bronchiolitis syndrome (BOS) arises from airway inflammation and the development of progressive narrowing and fibrosis in the small airways (for review, see Emtiazjoo and Wilkes 2013).

Passive antibody transfer models into $\mathrm{T}$ and B-cell-deficient recipients provide the most definitive evidence for the sufficiency of DSA to induce chronic rejection. Colvin and colleagues developed a model of chronic cardiac allograft vasculopathy by the repeated transfer over 28 days of either complement-fixing IgG2a or non-complement-fixing anti-MHC class I $\mathrm{mAb}$ into B6.Rag1 ${ }^{-/}$mice recipients of B10.BR hearts (for review, see Akiyoshi et al. 2012). Importantly, antibody to class I MHC antigens did not require complement deposition in the graft to induce antibody-mediated rejection, whereas Fc- and NK-dependent events were necessary.

Mohanakumar and colleagues have developed an intriguing mouse model in which immunopathology of chronic rejection results from the repeated administration of antiMHC class I antibodies intrabronchially into native lungs (Fukami et al. 2009). These mice develop marked $\mathrm{CD}^{+}{ }^{+} \mathrm{T}$ cell and $\mathrm{CD} 11 \mathrm{~b}^{+}$cell infiltration around the vessels and bronchioles of the lung by day 15, followed by epithelial hyperplasia, fibrosis, and occlusion of the distal airways by day 30 , histopathological features similar to chronic rejection in human lung transplantation. De novo production of antibodies and increased frequencies of Th17 cells specific for self-antigens, including K- $\alpha 1$-tubulin and collagen V, contributed to lung pathology (Fukami et al. 2012a), similar to reports on obliterative bronchiolitis in human and rat lung transplantation (Burlingham et al. 2007). Although there are several significant caveats for this model of antibody-mediated injury of native lungs, it nonetheless provides a tractable model for an investigation into the proximal causes of lung remodeling following antibodymediated injury.

Models involving the passive transfer of antibodies to induce chronic rejection do not provide opportunities to investigate the regulation of the antibody response that generates chronic rejection (vs. acute antibody-mediated rejection). Thus, the report by Kwun et al. (2012) of a chronic cardiac allograft rejection model in mice after alemtuzumab (antihuman CD52 $\mathrm{mAb}$ ) is noteworthy. Induction therapy with alemtuzumab in human kidney transplant recipients has been associated with increased incidence of serum alloantibody, C4d deposition, and antibody-mediated rejection. In transgenic mice expressing the human CD52 only on T 
A.S. Chong et al.

cells, alemtuzumab treatment resulted in profound peripheral T-cell depletion and prolonged survival of fully MHC-mismatched cardiac allografts. DSA was inhibited at $2 \mathrm{wk}$ posttransplantation, but increasing titers of DSA were detected in $50 \%$ of recipients at week $\geq 7$ posttransplantation. Hearts examined at $\geq 100 \mathrm{~d}$ posttransplantation show a striking dichotomy: those from recipients with DSA showing narrowing of vascular lumen due to neointimal thickening and fibrosis in the myocardium, whereas those from recipients without DSA having significantly reduced pathology. There was minimal T-cell infiltration of the grafts with cardiac allograft vasculopathy $(\mathrm{CAV})$, and the frequency of allospecific T cells producing interferon $\gamma($ IFN- $\gamma$ ) was comparable in the recipients with or without DSA. Thus, this mouse transplant model of T-cell depletion with alemtuzumab mimics the clinical outcome of human patients, wherein continuous de novo emergence of allospecific B cells and donor-specific antibodies, but not alloreactive T cells, was correlated with the development of CAV and fibrosis.

\section{Models Defining Antibody-Independent Roles for B Cells in Transplantation}

Basic understanding of the multiple properties of B cells suggests that B cells may play a role in graft rejection independently of alloantibodies. Several models have attempted to address this issue. The first was through the generation of mixed bone marrow chimeras in which all the B cells were class II deficient, whereas $50 \%$ of all the other cell types were class II sufficient (Noorchashm et al. 2006). In those mixed bone marrow chimeras, fully mismatched MHC cardiac allograft survival was markedly prolonged compared with control counterparts reconstituted with B-cell-deficient and wild-type bone marrows (median survival time, $>70$ vs. $9.5 \mathrm{~d}$ ). Mechanistically, deficiency in B-cell-mediated Ag presentation disrupted both alloantibody production and the progression of CD4 T-cell activation, suggesting that cognate $\mathrm{T}-\mathrm{B}$-cell interactions, alloantibodies, or both were necessary for acute rejection. More recently, $\mathrm{Ng}$ et al.
(2010) used B-cell-deficient hosts and the adoptive transfer of activated $T$ cells with or without $B$ cells to investigate the role of B cells in the maintenance of T-cell memory. The presence of B cells promoted the optimal activation, differentiation, and survival of alloreactive CD4 and CD8 $\mathrm{T}$ cells into functional memory cells, assessed by an accelerated rejection of allograft rejection; however, the effects were modest and the necessity for antibodies unclear. Thus, the definitive demonstration of antibody-independent function of B cells in allograft rejection will require a model system that has defective B cells but normalized alloantibodies, or that has normal $\mathrm{B}$ cells but no alloantibodies.

Recent reports indicate that a subset of regulatory B cells (Bregs) plays an important role in modulating rejection and facilitating allograft tolerance in two models of allogeneic islet transplantation following treatment with anti-T-cell IG and Mucin 1 (TIM-1) (Ding et al. 2011) or with anti-CD45RB in combination with antiTIM-1 (Lee et al. 2012). Bregs from these tolerant mice were enriched for expression of TIM-1, IL-10, and IL-4 and, upon adoptive transfer into B-cell-deficient recipients, were able to prolong allograft survival in a donor-specific and IL-10dependent manner. Whether regulatory B cells play an important role in other organ transplant models, or models of tolerance, remains to be determined. Nonetheless, these models provide important insight into the divergent roles of $\mathrm{B}$ cells in allotransplantation and highlight the caveat of adoptive transfer of a heterogeneous population of B cells that may contain both effector and regulatory alloreactive subsets, as well as a potential unwanted consequence of eliminating all B cells with panreactive antibodies.

\section{Antibodies and Graft Accommodation}

One of the least understood but clinically important concepts in regard to graft response to DSA is "accommodation," which was originally defined as an acquired resistance to antibodymediated injury in ABO-incompatible kidney allografts (Bach et al. 1991). A common histopathological hallmark of accommodation is C4d deposition without other signs of rejection- 
suggesting that antibody binding and early complement activation is intact but in the presence of regulatory pathways. In early hamster-to-rat heart transplantation models, inhibition of complement reproducibly induced accommodation associated with the expression of cytoprotective genes, A20 and B-cell lymphoma (Bcl)-2 (Bach et al. 1997), and the inhibition of the membrane attack complex of complement (Suhr et al. 2007). Ding and coworkers (Bobadilla et al. 2008) induced accommodation in xenogeneic rat hearts transplanted into $\mathrm{Rag}^{-/-}$ $\mathrm{Gal}^{-/-}$mice by repeated low-dose transfusion of anti-Gal IgG1 mAbs. Accommodation was confirmed by the acquired resistance to HAR to doses of anti-Gal IgG1 or IgG3 that caused HAR in freshly transplanted grafts and was associated with the up-regulated expression of the complement-regulatory proteins DAF, complement receptor 1-related gene/protein-y (Crry), and, to a lesser extent, CD59. More recent studies suggest that accommodation may be a more frequent clinical occurrence and that anti-HLA antibodies may also induce graft accommodation via increased expression of cytoprotective genes in vitro (Atz and Reed 2008; Iwasaki et al. 2012) and in vivo (Fukami et al. 2012b). In a model of single HLA A2-mismatched heterotopic heart transplantation in presensitized mice, accommodation was induced by the transfer of anti-HLA framework (mouse IgG2a) mAb into the donor to precondition the graft before transplantation (Fukami et al. 2012b). Increased expression of Bcl-2, Bcl- $\mathrm{x}_{\mathrm{L}}$, and hemoxygenase-1 genes was observed in the accommodated hearts, and silencing of Bcl-2 prevented accommodation. Many mechanistic issues remain unresolved, including whether different states of accommodation are elicited by different antibody specificities or isotypes (or IgG subclasses) and whether graft accommodation is mechanistically and clinically distinct from chronic rejection in recipients with high-titer DSA.

\section{MODELS OF TRANSPLANTATION TOLERANCE}

Mechanisms of T-cell tolerance exist naturally to prevent the onset of autoimmunity in ani- mals and humans, and efforts at inducing transplantation tolerance have attempted to harness these pathways. Mechanisms of self-tolerance include the deletion of autoreactive $\mathrm{T}$ cells in the thymus (central tolerance) or, for $\mathrm{T}$ cells that escape this negative selection, peripheral tolerance through deletion, intrinsic inactivation, or extrinsic suppression of effector T cells. In animals, transplantation tolerance can be confirmed by acceptance of donor but not third-party secondary grafts, a hallmark of donor specificity that correlates with low or undetectable T-cell responses upon stimulation with alloantigens in vitro (proliferation or IFN- $\gamma$ production) and with the absence of alloantibodies in vivo. Here, we discuss three different approaches leading to tolerance to allogeneic grafts in mice (see also Table 2).

\section{Induction of Central Tolerance with Mixed Chimerism}

The only prospective strategy so far that has allowed the prospective induction of transplantation tolerance in the clinic is the generation of donor-recipient chimerism that enables donor APCs to populate the host thymus to induce negative selection of donor-reactive $\mathrm{T}$ cells (Manilay et al. 1998). Early successful mouse models involved lethal doses of irradiation and reconstitution of the immune system with a mixture of donor and host bone marrow. Such a regimen can achieve life-long coexistence of donor and host hematopoietic cells and enable donor-specific tolerance of fully mismatched skin grafts, the most stringent transplant model (Sharabi et al. 1992; Wekerle et al. 2000). However, the toxicity of lethal irradiation prompted conditioning strategies to evolve toward nonmyeloablative regimens that include partial depletion/inactivation of host $\mathrm{T}$ cells rather than complete elimination. More recent approaches include facilitating cells, a bone marrow cell type that can promote engraftment (Kaufman et al. 1994), or infusion of regulatory $\mathrm{T}$ cells (Tregs) to further reduce graft-versus-host disease (GVHD) (Pilat et al. 2010).

Successes in mouse models have led to attempts at inducing mixed chimerism in preclin- 
A.S. Chong et al.

Table 2. Animal models of central and peripheral tolerance

\begin{tabular}{|c|c|c|c|c|}
\hline Tyре & $\begin{array}{l}\text { Tolerance } \\
\text { mechanism }\end{array}$ & $\begin{array}{l}\text { Induction } \\
\text { method }\end{array}$ & $\begin{array}{l}\text { Animal } \\
\text { models }\end{array}$ & References \\
\hline Central & Negative selection & Mixed chimerism & $\begin{array}{l}\text { Mice, cattle, dog, } \\
\text { miniature swine, } \\
\text { nonhuman primate }\end{array}$ & $\begin{array}{l}\text { For review, see Pasquet et al. } \\
\quad 2011\end{array}$ \\
\hline \multirow[t]{3}{*}{ Peripheral } & Deletion & $\begin{array}{l}\text { Costimulation } \\
\text { blockade }\end{array}$ & $\begin{array}{l}\text { Mice, rats, nonhuman } \\
\text { primates }\end{array}$ & $\begin{array}{l}\text { Li et al. 2001; Preston et al. } \\
\quad 2005\end{array}$ \\
\hline & Anergy & $\begin{array}{l}\text { Costimulation } \\
\text { blockade }\end{array}$ & $\begin{array}{l}\text { Mice, rats, nonhuman } \\
\text { primates }\end{array}$ & $\begin{array}{l}\text { Lenschow et al. 1992; Lin } \\
\text { et al. 1993; Wekerle et al. } \\
\text { 2002; Preston et al. } 2005\end{array}$ \\
\hline & Regulation & $\begin{array}{l}\text { Costimulation } \\
\text { blockade }\end{array}$ & Mice & Quezada et al. 2005 \\
\hline
\end{tabular}

ical models, including the miniature swine, nonhuman primates, and ultimately, humans. In those studies, the recipients are preconditioned with nonmyeloablative regimens to facilitate allogeneic bone marrow engraftment. Although durable mixed chimerism was rarely achieved (Larsen et al. 2010), long-term acceptance of kidney allografts in a subset of the recipients was attained (Kawai et al. 1995). In a classic bench-to-bedside and then returning to the bench, efforts are now focused on identifying new ways to achieve stable mixed chimerism in the clinic, because this state resulted in the most robust form of tolerance in rodents, and also in understanding how transient chimerism favors the development of operational tolerance.

\section{Induction of Peripheral Tolerance with Costimulation Blockade}

Activation of T cells depends on engagement by the T-cell receptor (TCR) simultaneously with ligation of costimulatory receptors, of which CD28 is the predominant one on naïve T cells. Once stimulated, T cells up-regulate other costimulatory molecules that are important for the activation of effector and memory $\mathrm{T}$ cells, including CD154 (the ligand for CD40, a receptor expressed on APCs that promotes their activation), and CD152 (cytotoxic T-lymphocyte antigen 4 [CTLA-4], an inhibitory receptor that can terminate T-cell activation) (Alegre and Fallarino 2006). Blockade of activating costimulatory receptors during TCR engagement can re- sult in T-cell death (Li et al. 2001) or anergy (durable hyporesponsiveness) (Wekerle et al. 2002), therefore predicting that costimulation blockade therapies administered at the time of transplantation (when only alloreactive $\mathrm{T}$ cells should be engaged) would induce transplantation tolerance. This prediction has been shown to be correct in multiple mouse transplantation models.

CD28 and cytotoxic T-lymphocyte antigen 4 (CTLA-4) share the same ligands, CD80 (B71) and CD86 (B7-2), but the affinity of CTLA-4 for its binding partners is greater than that of CD28, allowing CTLA-4 to sequester the ligands and thus prevent/minimize CD28 engagement (Alegre et al. 2001). The first-generation costimulation blockade reagent, CTLA-4Ig, was a fusion protein of the extracellular domain of CTLA-4 and the Fc portion of human IgG. This construct binds B7 molecules with high affinity and prevents activation of naïve $\mathrm{T}$ cells (Alegre and Fallarino 2006). Administration of CTLA-4Ig at the time of transplantation was initially shown to prevent rejection of xenogeneic human pancreatic islets transplanted into diabetic mice (Lenschow et al. 1992) and, when injected shortly after transplantation, of allogeneic cardiac transplants in rat (Lin et al. 1993). Although CTLA-4Ig can induce long-term allograft survival, it has failed to induce true immunological tolerance in some mouse models of allograft transplantation. This may be due to the ability of CTLA-4Ig to inhibit both the engagement of the positive costimulator CD28 
and the negative costimulator CTLA-4 on effector $\mathrm{T}$ cells and on Tregs. Specific inhibition of CTLA-4 has been shown to reduce the intrinsic restraint of effector $\mathrm{T}$ cells as well as diminish numbers and suppressive function of Tregs (Charbonnier et al. 2012; Riella et al. 2012). Thus, there is a need to understand the complex effects of CTLA-4Ig or higher-affinity variants, on different subsets of immune cells, because these insights may eventually lead to the optimal use of this reagent in the clinic, and possibly to the successful induction of tolerance.

Blockade of the CD40/CD154 pathway using anti-CD154 mAb is one of the most effective approaches in rodents at inducing donor-specific tolerance, especially if combined with an infusion of donor cells administered either before or on the day of solid organ transplantation. This regimen not only reduces activation and promotes death of alloreactive T cells, but also promotes the generation of Tregs, and these mechanisms collectively contribute to a robust state of tolerance (Quezada et al. 2005). Anti-CD154 was also successful at inducing long-term acceptance of renal allografts in nonhuman primates (Preston et al. 2005), leading to much optimism for achieving tolerance in the clinic. AntiCD154-based models of tolerance permit basic investigations into transplantation tolerance; however, thromboembolic complications observed in humans treated with anti-CD154 $\mathrm{mAb}$ have stymied further clinical development. This was due to CD154 expression on human but not mouse platelets (Koyama et al. 2004). Nonetheless, the efficacy of anti-CD154 has prompted the development of an alternative approach of targeting CD40. The challenge with this approach is to identify reagents that lack agonistic activity when bound to CD40, while working comparably to anti-CD154 in preclinical models and humans (Adams et al. 2005; Aoyagi et al. 2009; Badell et al. 2012).

Because memory $\mathrm{T}$ cells up-regulate other costimulatory and adhesion molecules and do not rely as much on CD28 for their activation, they are resistant to costimulation blockade with CTLA-4Ig (Valujskikh and Li 2007). Animal models have been developed to test the ability of antibodies to such adhesion and costimula- tory molecules to prevent activation of memory alloreactive T cells (Damle et al. 1992; Curry et al. 2004; Vu et al. 2006; Badell et al. 2010). It is unclear whether these approaches will be superior to conventional calcineurin inhibitors that can block TCR signaling in both naïve and memory T cells; nonetheless, these approaches of targeting adhesion molecules can significantly promote graft survival in nonhuman primates and point to the potential of controlling recall alloreactive responses with rationally designed biologics (Badell et al. 2010). The induction of tolerance in the face of a significant memory alloreactive T-cell repertoire represents a major area of investigation that has strong clinical relevance.

\section{Spontaneous Transplant Models}

In certain mouse strain combinations of donors and recipients, the kidney allografts are spontaneously accepted without immunosuppression or tolerogenic therapies despite MHC and minor antigen mismatches. Although this outcome does not recapitulate the vast majority of clinical data, they have been used to shed light into the immunological pathways that can achieve tolerance in a tissue-specific manner. The long-term survival $(>60 \mathrm{~d})$ of $\mathrm{DBA} / 2$ $\left(\mathrm{H} 2^{\mathrm{d}}\right)$ kidneys $\rightarrow \mathrm{C} 57 \mathrm{BL} / 6 \quad\left(\mathrm{H}-2^{\mathrm{b}}\right)$ recipients was originally reported by Russell and colleagues (1978). Spontaneous acceptance of complete MHC-mismatched renal allografts has also been reported in several other strain combinations including A/J (H-2 $\left.{ }^{\mathrm{a}}\right) \rightarrow \mathrm{C} 57 \mathrm{BL} / 6$ (Bickerstaff et al. 2008). Long-term survival was accompanied by an absence of renal allograft injury by histological analysis and without a rise in recipient serum creatinine levels. Essential roles for transforming growth factor $\beta$ (TGF- $\beta$ ) signaling and regulatory $\mathrm{T}$ cells (Bickerstaff et al. 2001), as well as (idoleamine-2,3-dioxygenase [indoleamine-pyrrole 2,3-dioxygenase [IDO]) signaling, which increased over time in graftresident dendritic cells, have been reported (Cooket al. 2008). Thirty percent of these kidney recipient mice with detectable IDO-producing dendritic cells accepted donor skin grafts without any immunosuppression, thus formally 
A.S. Chong et al.

showing tolerance (Cook et al. 2008). In another strain combination, C57BL/6 kidney allografts into B10.BR recipients also showed spontaneous graft acceptance and tolerance to subsequent skin allografts (Wang et al. 2011). Increased Foxp3 mRNA expression was observed in those kidney allografts, suggesting a role for Tregs. Thus, these kidney models, although not reflective of the clinical situation, provide a unique opportunity to study the protolerogenic environment of the allograft.

Liver allografts are accepted in many rat and mouse strain combinations in the absence of immunosuppression. The acceptance of these allografts has been shown to be dependent upon $\mathrm{CD} 25^{+}$regulatory cells ( $\mathrm{Li}$ et al. 2008), invariant natural killer cells (Morita et al. 2007), Fas-FasL (Uchiyama et al. 2002), IFN- $\gamma$ (Mele et al. 2003), CTLA-4 (Li et al. 2005), and PD-1 signaling (Morita et al. 2010), and low levels of NF- $\kappa \mathrm{B}$ in liver dendritic cells (Ma et al. 2009). The broad spectrum of peripheral tolerance mechanisms, including deletion, anergy, and regulation, implicated in the liver allograft model underscores the critical role of the transplanted organ in facilitating the development of immunological tolerance, and also the complexity of the tolerant state. The tolerogenicity of the allogeneic liver is recapitulated in clinical transplantation, and thus further investigation with this model of tolerance is warranted, despite the rather enormous technical challenges of performing successful liver transplantation in mice.

Much work remains to be performed in order to reach an understanding of why certain organ types and certain histoincompatibilities promote graft acceptance, and to translate these insights into tolerogenic strategies for the clinic.

\section{CONCLUDING REMARKS}

It is clear that mouse models provide unique opportunities to gain insights into mechanisms of rejection and to test approaches that prevent rejection and induce transplantation tolerance. Nonetheless, there are limitations to the information generated from these models. The exclusive use of inbred mice with limited genetic di- versity may mask pathways of rejection or tolerance that exist in humans. Indeed, the wide range of rejection tempos in transplantation with outbred mice, spanning HAR to chronic rejection, contrasting with the unimodal acute rejection of cardiac allografts observed when using inbred strains, underscore this concern (Reichenbach et al. 2013). Obesity, age, and the infectious history, as well as organ preservation times (Wehner et al. 2010; Oberhuber et al. 2012; Denecke et al. 2013), which are highly variable in human transplantation, can also have profound effects on immune responses and graft outcomes. Understanding these caveats and modifying the mouse transplantation models to capture these variables may introduce complexities into the investigation but may allow for a more accurate translation of findings from mice to man.

\section{ACKNOWLEDGMENTS}

We thank Dr. James W. Williams for his comments on the manuscript. This work is supported in part by grants NIAID P01AI97113 to A.S.C. and M.-L.A.; RO1 AI071080 to M.-L.A.; and ROTRF 979162997 and NIAID R01 AI072630 to A.S.C. M.L.M. is funded by a Cardiovascular Pathophysiology and Biochemistry Training Grant (T32 HL07237) and an AHA Predoctoral Fellowship (13PRE14550022).

\section{REFERENCES}

Adams AB, Shirasugi N, Jones TR, Durham MM, Strobert
EA, Cowan S, Rees P, Hendrix R, Price K, Kenyon NS, et
al. 2005. Development of a chimeric anti-CD40 mono-
clonal antibody that synergizes with LEA29Y to prolong
islet allograft survival. J Immunol 174: 542-550.
Akiyoshi T, Hirohashi T, Alessandrini A, Chase CM, Farkash
EA, Neal Smith R, Madsen JC, Russell PS, Colvin RB.
2012. Role of complement and NK cells in antibody me-
diated rejection. Hum Immunol 73: 1226-1232.
Alegre ML, Fallarino F. 2006. Mechanisms of CTLA-4Ig in
tolerance induction. Curr Pharm Des 12: 149-160.
Alegre ML, Frauwirth KA, Thompson CB. 2001. T-cell reg-
ulation by CD28 and CTLA-4. Nat Rev Immunol 1: $220-$
228.
Aoyagi T, Yamashita K, Suzuki T, Uno M, Goto R, Taniguchi
M, Miura T, Okimura K, Itoh T, Shimizu A, et al. 2009. A
human anti-CD40 monoclonal antibody, 4D11, for kid- 
ney transplantation in cynomolgus monkeys: Induction and maintenance therapy. Am J Transplant 9: 1732-1741.

Atkinson C, Horsley J, Rhind-Tutt S, Charman S, Phillpotts CJ, Wallwork J, Goddard MJ. 2004. Neointimal smooth muscle cells in human cardiac allograft coronary artery vasculopathy are of donor origin. J Heart Lung Transplant 23: $427-435$.

Atz ME, Reed EF. 2008. Role of anti-MHC class I antibody in facilitating transplant accommodation. Critical Rev Immunol 28: 485-511.

Bach FH, Turman MA, Vercellotti GM, Platt JL, Dalmasso AP. 1991. Accommodation: A working paradigm for progressing toward clinical discordant xenografting. Transplant Proc 23: 205-207.

Bach FH, Ferran C, Hechenleitner P, Mark W, Koyamada N, Miyatake T, Winkler H, Badrichani A, Candinas D, Hancock WW. 1997. Accommodation of vascularized xenografts: Expression of "protective genes" by donor endothelial cells in a host Th2 cytokine environment. Nat Med 3: 196-204.

Badell IR, Russell MC, Thompson PW, Turner AP, Weaver TA, Robertson JM, Avila JG, Cano JA, Johnson BE, Song $\mathrm{M}$, et al. 2010. LFA-1-specific therapy prolongs allograft survival in rhesus macaques. J Clin Invest 120: 45204531.

Badell IR, Thompson PW, Turner AP, Russell MC, Avila JG, Cano JA, Robertson JM, Leopardi FV, Strobert EA, Iwakoshi NN, et al. 2012. Nondepleting anti-CD40-based therapy prolongs allograft survival in nonhuman primates. Am J Transplant 12: 126-135.

Baldwin WM III, Valujskikh A, Fairchild RL. 2010. Antibody-mediated rejection: Emergence of animal models to answer clinical questions. Am J Transplant 10: 11351142.

Bergstresser PR, Toews GB, Gilliam JN, Streilein JW. 1980a. Unusual numbers and distributions of Langerhans cells in skin with unique immunologic properties. J Invest Dermatol 74: 312-314.

Bergstresser PR, Fletcher CR, Streilein JW. 1980b. Surface densities of Langerhans cells in relation to rodent epidermal sites with special immunologic properties. J Invest Dermatol 74: 77-80.

Bickerstaff AA, Wang JJ, Pelletier RP, Orosz CG. 2001. Murine renal allografts: Spontaneous acceptance is associated with regulated $\mathrm{T}$ cell-mediated immunity. J Immunol 167: $4821-4827$.

Bickerstaff A, Nozaki T, Wang J-J, Pelletier R, Hadley G, Nadasdy G, Fairchild RL. 2008. Acute humoral rejection of renal allografts in CCR $5^{-/-}$recipients. Am J Transplant 8: 557-566.

Billingham RE, Medawar PB. 1951. Technique of free skin grafting in mammals. J Exp Biol 28: 385-391.

Bobadilla JL, Love RB, Jankowska-Gan E, Xu Q, Haynes LD, Braun RK, Hayney MS, Munoz del Rio A, Meyer K, Greenspan DS, et al. 2008. Th-17, monokines, collagen type $\mathrm{V}$, and primary graft dysfunction in lung transplantation. Am J Respir Crit Care Med 177: 660-668.

Burlingham WJ, Love RB, Jankowska-Gan E, Haynes LD, Xu Q, Bobadilla JL, Meyer KC, Hayney MS, Braun RK, Greenspan DS, et al. 2007. IL-17-dependent cellular immunity to collagen type $\mathrm{V}$ predisposes to obliterative bronchiolitis in human lung transplants. $J$ Clin Invest 117: 3498-3506.

Burns AM, Chong AS. 2011. Alloantibodies prevent the induction of transplantation tolerance by enhancing alloreactive T cell priming. J Immunol 186: 214-221.

Calcagni M, Althaus MK, Knapik AD, Hegland N, Contaldo C, Giovanoli P, Lindenblatt N. 2011. In vivo visualization of the origination of skin graft vasculature in a wild-type/ GFP crossover model. Microvasc Res 82: 237-245.

Capla JM, Ceradini DJ, Tepper OM, Callaghan MJ, Bhatt KA, Galiano RD, Levine JP, Gurtner GC. 2006. Skin graft vascularization involves precisely regulated regression and replacement of endothelial cells through both angiogenesis and vasculogenesis. Plast Reconstr Surg 117: 836844.

Charbonnier LM, Vokaer B, Lemaitre PH, Field KA, Leo O, Le Moine A. 2012. CTLA-4Ig restores rejection of MHC class-II mismatched allografts by disabling IL-2-expanded regulatory T cells. Am J Transplant 12: 2313-2321.

Chen H-D, Silvers WK. 1983. Influence of Langerhans cells on the survial of H-Y incompatible skin grafts in rats. $J$ Invest Dermatol 81: 20-23.

Cook CH, Bickerstaff AA, Wang J-J, Nadasdy T, Della Pelle P, Colvin RB, Orosz CG. 2008. Spontaneous renal allograft acceptance associated with "regulatory" dendritic cells and IDO. J Immunol 180: 3103-3112.

Corry RJ, Winn HJ, Russell PS. 1973. Primarily vascularized allografts of hearts in mice. The role of $\mathrm{H}-2 \mathrm{D}, \mathrm{H}-2 \mathrm{~K}$, and non-H-2 antigens in rejection. Transplantation 16: 343350.

Curry AJ, Chikwe J, Smith XG, Cai M, Schwarz H, Bradley JA, Bolton EM. 2004. OX40 (CD134) blockade inhibits the co-stimulatory cascade and promotes heart allograft survival. Transplantation 78: 807-814.

Damle NK, Klussman K, Linsley P, Aruffo A. 1992. Differential costimulatory effects of adhesion molecules B7, ICAM-1, LFA-3 and VCAM-1 on resting and antigenprimed $\mathrm{CD}^{+}{ }^{+} \mathrm{T}$ lymphocytes. J Immunol 148: 19851989.

Denecke C, Yuan X, Ge X, Kim IK, Bedi D, Boenisch O, Weiland A, Jurisch A, Kotsch K, Pratschke J, et al. 2013. Synergistic effects of prolonged warm ischemia and donor age on the immune response following donation after cardiac death kidney transplantation. Surgery 153: 249261.

Ding JW, Zhou T, Zeng H, Ma L, Verbeek JS, Yin D, Shen J, Chong AS. 2008a. Hyperacute rejection by anti-Gal IgG1, $\operatorname{IgG} 2 \mathrm{a}$, and IgG2 $\mathrm{b}$ is dependent on complement and Fc- $\gamma$ receptors. J Immunol 180: 261-268.

Ding JW, Zhou T, Ma L, Yin D, Shen J, Ding CP, Tang IY, Byrne GW, Chong AS. 2008b. Expression of complement regulatory proteins in accommodated xenografts induced by anti- $\alpha$-Gal IgG1 in a rat-to-mouse model. $A m$ J Transplant 8: 32-40.

Ding Q, Yeung M, Camirand G, Zeng Q, Akiba H, Yagita H, Chalasani G, Sayegh MH, Najafian N, Rothstein DM. 2011. Regulatory B cells are identified by expression of TIM-1 and can be induced through TIM-1 ligation to promote tolerance in mice. J Clin Invest 121: 3645-3656.

Emtiazjoo AM, Wilkes DS. 2013. Humoral immunity and the development of obliterative bronchiolitis post lung 
A.S. Chong et al.

transplantation-Is there a link? Am J Respir Cell Mol Biol 48: 145-149.

Fukami N, Ramachandran S, Saini D, Walter M, Chapman W, Patterson GA, Mohanakumar T. 2009. Antibodies to MHC class I induce autoimmunity: Role in the pathogenesis of chronic rejection. J Immunol 182: 309-318.

Fukami N, Ramachandran S, Takenaka M, Weber J, Subramanian V, Mohanakumar T. 2012a. An obligatory role for lung infiltrating $\mathrm{B}$ cells in the immunopathogenesis of obliterative airway disease induced by antibodies to MHC class I molecules. Am J Transplant 12: 867-876.

Fukami N, Ramachandran S, Narayanan K, Liu W, Nath DS, Jendrisak M, Chapman W, Mohanakumar T. 2012b. Mechanism of accommodation in a sensitized human leukocyte antigen transgenic murine cardiac transplant model. Transplantation 93: 364-372.

Ge F, Gong W. 2011. Strategies for successfully establishing a kidney transplant in a mouse model. Exp Clin Transplant 9: $287-294$

Gibson T, Medawar PB. 1943. The fate of skin homografts in man. J Anat 77: 299-316.

Hagensen MK, Shim J, Falk E, Bentzon JF. 2011. Flanking recipient vasculature, not circulating progenitor cells, contributes to endothelium and smooth muscle in murine allograft vasculopathy. Arterioscler Thromb Vasc Biol 31: $808-813$.

Hattori Y, Bucy RP, Kubota Y, Baldwin WM III, Fairchild RL. 2012. Antibody-mediated rejection of single class I MHC-disparate cardiac allografts. Am J Transplant 12: 2017-2028.

He C, Schenk S, Zhang Q, Valujskikh A, Bayer J, Fairchild RL, Heeger PS. 2004. Effects of T cell frequency and graft size on transplant outcome in mice. J Immunol 172: 240 247.

Iwasaki K, Miwa Y, Ogawa H, Yazaki S, Iwamoto M, Furusawa T, Onishi A, Kuzuya T, Haneda M, Watarai Y, et al. 2012. Comparative study on signal transduction in endothelial cells after anti-a/b and human leukocyte antigen antibody reaction: Implication of accommodation. Transplantation 93: 390-397.

Kaufman CL, Colson YL, Wren SM, Watkins S, Simmons RL, Ildstad ST. 1994. Phenotypic characterization of a novel bone marrow-derived cell that facilitates engraftment of allogeneic bone marrow stem cells. Blood 84: 2436-2446.

Kawai T, Cosimi AB, Colvin RB, Powelson J, Eason J, Kozlowski T, Sykes M, Monroy R, Tanaka M, Sachs DH. 1995. Mixed allogeneic chimerism and renal allograft tolerance in cynomolgus monkeys. Transplantation 59: $256-562$.

Koene RA, Gerlag PG, Hagemann JF, van Haelst UJ, Wijdeveld PG. 1973. Hyperacute rejection of skin allografts in the mouse by the administration of alloantibody and rabbit complement. J Immunol 111: 520-526.

Koyama I, Kawai T, Andrews D, Boskovic S, Nadazdin O, Wee SL, Sogawa H, Wu DL, Smith RN, Colvin RB, et al. 2004. Thrombophilia associated with anti-CD154 monoclonal antibody treatment and its prophylaxis in nonhuman primates. Transplantation 77: 460-462.

Krasinskas AM, Eiref SD, McLean AD, Kreisel D, Gelman AE, Popma SH, Moore JS, Rosengard BR. 2000. Replacement of graft-resident donor-type antigen presenting cells alters the tempo and pathogenesis of murine cardiac allograft rejection. Transplantation 70: 514-521.

Kwun J, Malarkannnan S, Burlingham WJ, Knechtle SJ. 2011. Primary vascularization of the graft determines the immunodominance of murine minor $\mathrm{H}$ antigens during organ transplantation. J Immunol 187: 39974006.

Kwun J, Oh BC, Gibby AC, Ruhil R, Lu VT, Kim DW, Page EK, Bulut OP, Song MQ, Farris AB, et al. 2012. Patterns of de novo allo B cells and antibody formation in chronic cardiac allograft rejection after alemtuzumab treatment. Am J Transplant 12: 2641-2651.

Lafuse WP, McCormick JF, Melvold RW, David CS. 1981. Serological and biochemical analysis of Ia molecules in the I-A mutant B6.C-H-2 ${ }^{\mathrm{bm} 12}$. Transplantation 31: $434-$ 438.

Larsen CP, Page A, Linzie KH, Russell M, Deane T, Stempora L, Strobert E, Penedo MC, Ward T, Wiseman R, et al. 2010. An MHC-defined primate model reveals significant rejection of bone marrow after mixed chimerism induction despite full MHC matching. Am J Transplant 10: 2396-2409.

Lee KM, Kim JI, Stott R, Soohoo J, O'Connor MR, Yeh H, Zhao G, Eliades P, Fox C, Cheng N, et al. 2012. Anti$\mathrm{CD} 45 \mathrm{RB} /$ anti-TIM-1-induced tolerance requires regulatory B cells. Am J Transplant 12: 2072-2078.

Lenschow DJ, Zeng Y, Thistlethwaite JR, Montag A, Brady W, Gibson MG, Linsley PS, Bluestone JA. 1992. Longterm survival of xenogeneic pancreatic islet grafts induced by CTLA-4Ig. Science 257: 789-792.

Li W, Lu L, Wang Z, Wang L, Fung JJ, Thomson AW, Qian S. 2001. Costimulation blockade promotes the apoptotic death of graft-infiltrating $\mathrm{T}$ cells and prolongs survival of hepatic allografts from FLT3L-treated donors. Transplantation 72: 1423-1432.

Li W, Zheng XX, Kuhr CS, Perkins JD. 2005. CTLA-4 engagement is required for induction of murine liver transplant spontaneous tolerance. Am J Transplant 5: 978-986.

Li W, Kuhr CS, Zheng XX, Carper K, Thomson AW, Reyes JD, Perkins JD. 2008. New insights into mechanisms of spontaneous liver transplant tolerance: The role of Foxp3-expressing $\mathrm{CD} 25^{+} \mathrm{CD} 4^{+}$regulatory T cells. Am J Transplant 8: 1639-1651.

Li Q, Peng Q, Xing G, Li K, Wang N, Farrar CA, Meader L, Sacks SH, Zhou W. 2010. Deficiency of C5aR prolongs renal allograft survival. J Am Soc Nephrol 21: 1344-1353.

Lin H, Bolling SF, Linsley PS, Wei RQ, Gordon D, Thompson CB, Turka LA. 1993. Long-term acceptance of major histocompatibility complex mismatched cardiac allografts induced by CTLA-4Ig plus donor-specific transfusion. J Exp Med 178: 1801-1806.

Lindenblatt N, Calcagni M, Contaldo C, Menger MD, Giovanoli P, Vollmar B. 2008. A new model for studying the revascularization of skin grafts in vivo: The role of angiogenesis. Plast Reconstr Surg 122: 1669-1680.

Lu WH, Palatnik K, Fishbein GA, Lai C, Levi DS, Perens G, Alejos J, Kobashigawa J, Fishbein MC. 2011. Diverse morphologic manifestations of cardiac allograft vasculopathy: A pathologic study of 64 allograft hearts. J Heart Lung Transplant 30: 1044-1050.

Ma L-L, Gao X, Liu L, Xiang Z, Blackwell TS, Williams P, Chari RS, Yin DP. 2009. CpG oligodeoxynucleotide trig- 
gers the liver inflammatory reaction and abrogates spontaneous tolerance. Liver Transpl 15: 915-923.

Manilay JO, Pearson DA, Sergio JJ, Swenson KG, Sykes M. 1998. Intrathymic deletion of alloreactive T cells in mixed bone marrow chimeras prepared with a nonmyeloablative conditioning regimen. Transplantation 66: 96-102.

McFarland HI, Rosenberg AS. 2009. Skin allograft rejection. Curr Protoc Immunol 4: 4.

McKenzie IFC, Morgan CM, Sanderin MS, Michaelides MM, Melvold RW, Kohn HL. 1979. B6.C-H-2 ${ }^{\text {bm12 }}$, a new $\mathrm{H}-2$ mutation in the I region in the mouse. J Exp Med 150: 1323-1338.

Medawar PB. 1944. The behavior and fate of skin autografts and skin homografts in rabbits. J Anat 78: 176-199.

Medawar PB. 1945. A second study of the behaviour and fate of skin homografts in rabbits. J Anat 79: 157-177.

Mele TS, Kneteman NM, Zhu L-F, Ramassar V, Urmson J, Halloran B, Churchill TA, Jewell L, Kane K, Halloran PF. 2003. IFN- $\gamma$ is an absolute requirement for spontaneous acceptance of liver allografts. Am J Transplant 3: 942-951.

Meng L, Wu Z, Wang Y, Lassman C, Busuttil RW, Zhai Y, Kupiec-Weglinski JW, et al. 2008. Differential impact of CD154 costimulation blockade on alloreactive effector and regulatory $\mathrm{T}$ cells in murine renal transplant recipients. Transplantation 85: 1332-1338.

Mengel M, Husain S, Hidalgo L, Sis B. 2012. Phenotypes of antibody-mediated rejection in organ transplants. Transpl Int 25: 611-622.

Mengle-Gaw L, Conner S, McDevitt HO, Fathman CG. 1984. Gene conversion between murine class II major histocompatibility complex loci: Functional and molecular evidence from the bm12 mutant. J Exp Med 160: 1184-1194.

Minami E, Laflamme MA, Saffitz JE, Murry CE. 2005. Extracardiac progenitor cells repopulate most major cell types in the transplanted human heart. Circulation 112: 2951-2958.

Morgan BP. 1995. Complement regulatory molecules: Application to therapy and transplantation. Immunol Today 16: $257-259$.

Morita M, Fujino M, Li X-K, Kimura H, Nakayama T, Taniguchi M, Sugioka A. 2007. Spontaneous tolerance involving natural killer $\mathrm{T}$ cells after hepatic grafting in mice. Transplant Immunol 18: 142-145.

Morita M, Fujino M, Jiang G, Kitazawa Y, Xie L, Azuma M Yagita H, Nagao S, Sugioka A, Kurosawa Y, et al. 2010. PD-1/B7-H1 interaction contribute to the spontaneous acceptance of mouse liver allograft. Am J Transplant 10: $40-46$.

$\mathrm{Ng}$ YH, Oberbarnscheidt MH, Chandramoorthy HC, Hoffman R, Chalasani G. 2010. B cells help alloreactive T cells differentiate into memory T cells. Am J Transplant 10: 1970-1980.

Noorchashm H, Reed AJ, Rostami SY, Mozaffari R, Zekavat G, Koeberlein B, Caton AJ, Naji A. 2006. B cell-mediated antigen presentation is required for the pathogenesis of acute cardiac allograft rejection. J Immunol 177: 77157722.

Nozaki T, Amano H, Bickerstaff A, Orosz CG, Novick AC, Tanabe K, Fairchild RL. 2007. Antibody-mediated rejec- tion of cardiac allografts in CCR5-deficient recipients. $J$ Immunol 179: 5238-5245.

Oberhuber R, Ge X, Tullius SG. 2012. Donor age-specific injury and immune responses. Am J Transplant 12: 3842.

Pasquet L, Joffre O, Santolaria T, van Meerwijk JP. 2011. Hematopoietic chimerism and transplantation tolerance: A role for regulatory T cells. Front Immunol 2: 80.

Pilat N, Baranyi U, Klaus C, Jaeckel E, Mpofu N, Wrba F, Golshayan D, Muehlbacher F, Wekerle T. 2010. Treg-therapy allows mixed chimerism and transplantation tolerance without cytoreductive conditioning. Am J Transplant 10: 751-762.

Pratt JR, Basheer SA, Sacks SH. 2002. Local synthesis of complement component $\mathrm{C} 3$ regulates acute renal transplant rejection. Nat Med 8: 582-587.

Preston EH, Xu H, Dhanireddy KK, Pearl JP, Leopardi FV, Starost MF, Hale DA, Kirk AD. 2005. IDEC-131 (antiCD154), sirolimus and donor-specific transfusion facilitate operational tolerance in non-human primates. Am J Transplant 5: 1032-1041.

Quezada SA, Bennett K, Blazar BR, Rudensky AY, Sakaguchi S, Noelle RJ. 2005. Analysis of the underlying cellular mechanisms of anti-CD154-induced graft tolerance: The interplay of clonal anergy and immune regulation. J Im munol 175: 771-779.

Rahimi S, Qian Z, Layton J, Fox-Talbot K, Baldwin WM III, Wasowska BA. 2004. Non-complement- and complement-activating antibodies synergize to cause rejection of cardiac allografts. Am J Transplant 4: 326-334.

Reichenbach DK, Li Q, Hoffman RA, Williams AL, Shlomchik WD, Rothstein DM, Demetris AJ, Lakkis FG. 2013. Allograft outcomes in outbred mice. Am J Transplant 13: 580-588.

Riella LV, Liu T, Yang J, Chock S, Shimizu T, Mfarrej B, Batal I, Xiao X, Sayegh MH, Chandraker A. 2012. Deleterious effect of CTLA-4Ig on a Treg-dependent transplant model. Am J Transplant 12: 846-855.

Russell PS, Chase CM, Colvin RB, Plate JMD. 1978. Kidney transplants in mice: An analysis of the immune status of mice bearing long-ter, $\mathrm{H}-2$ incompatible transplants. $J$ Exp Med 147: 1449-1468.

Schenk S, Kish DD, He C, El-Sawy T, Chiffoleau E, Chen C, Wu Z, Sandner S, Gorbachev AV, Fukamachi K, et al. 2005. Alloreactive $\mathrm{T}$ cell responses and acute rejection of single class II MHC disparate heart allografts is under strict regulation by $\mathrm{CD} 4{ }^{+} \mathrm{CD} 25^{+} \mathrm{T}$ cells. J Immunol 174: 3741-3748.

Schenk AD, Nozaki T, Rabant M, Valujskikh A, Fairchild RL. 2008. Donor-reactive CD8 memory T cells infiltrate cardiac allografts within 24 -h posttransplant in naive recipients. Am J Transplant 8: 1652-1661.

Schenk AD, Gorbacheva V, Rabant M, Fairchild RL, Valujskikh A. 2009. Effector functions of donor-reactive CD8 memory T cells are dependent on ICOS induced during division in cardiac grafts. Am J Transplant 9: 64-73.

Sharabi Y, Abraham VS, Sykes M, Sachs DH. 1992. Mixed allogeneic chimeras prepared by a non-myeloablative regimen: Requirement for chimerism to maintain tolerance. Bone Marrow Transplant 9: 191-197. 
A.S. Chong et al.

Shimizu I, Smith NR, Zhao G, Medof E, Sykes M. 2006 Decay-accelerating factor prevents acute humoral rejection induced by low levels of anti- $\alpha$ Gal natural antibodies. Transplantation 81: 95-100.

Skoskiewicz M, Chase C, Winn HJ, Russell PS. 1973. Kidney transplants between mice of graded immunogenetic diversity. Transplant Proc 5: 721-725.

Smith RN, Colvin RB. 2012. Chronic alloantibody mediated rejection. Semin Immunol 24: 115-121.

Soleimani B, Lechler RI, Hornick PI, George AJ. 2006. Role of alloantibodies in the pathogenesis of graft arteriosclerosis in cardiac transplantation. Am J Transplant 6: 17811785.

Stegall MD, Chedid MF, Cornell LD. 2012. The role of complement in antibody-mediated rejection in kidney transplantation. Nat Rev Nephrol 8: 670-678.

Steinmuller D. 1984. Skin grafting. Methods Enzymol 108: $28-35$.

Suhr BD, Black SM, Guzman-Paz M, Matas AJ, Dalmasso AP. 2007. Inhibition of the membrane attack complex of complement for induction of accommodation in the hamster-to-rat heart transplant model. Xenotransplantation 14: 572-579.

Uchiyama H, Kishihara K, Minagawa R, Hashimoto K, Sugimachi K, Nomoto K. 2002. Crucial Fas-Fas ligand interaction in spontaneous acceptance of hepatic allografts in mice. Immunology 105: 450-457.

Valujskikh A, Li XC. 2007. Frontiers in nephrology: T cell memory as a barrier to transplant tolerance. J Am Soc Nephrol 18: 2252-2261.

Vu MD, Clarkson MR, Yagita H, Turka LA, Sayegh MH, Li XC. 2006. Critical, but conditional, role of OX40 in mem- ory T cell-mediated rejection. J Immunol 176: $1394-$ 1401.

Wang C, Cordoba S, Hu M, Bertolino P, Bowen DG, Sharland AF, Allen RD, Alexander SI, McCaughan GW, Bishop GA. 2011. Spontaneous acceptance of mouse kidney allografts is associated with increased Foxp3 expression and differences in the $\mathrm{B}$ and $\mathrm{T}$ cell compartments. Transplant Immunol 24: 149-156.

Wasowska BA, Qian Z, Cangello DL, Behrens E, Van Tran K, Layton J, Sanfilippo F, Baldwin WM III. 2001. Passive transfer of alloantibodies restores acute cardiac rejection in IgKO mice. Transplantation 71: 727-736.

Wehner JR III, Baldwin WM. 2010. Cardiac allograft vasculopathy: Do adipocytes bridge alloimmune and metabolic risk. Curr Opin Organ Transplant 15: 639-644.

Wekerle T, Kurtz J, Ito H, Ronquillo JV, Dong V, Zhao G, Shaffer J, Sayegh MH, Sykes M. 2000. Allogeneic bone marrow transplantation with co-stimulatory blockade induces macrochimerism and tolerance without cytoreductive host treatment. Nat Med 6: 464-469.

Wekerle T, Kurtz J, Bigenzahn S, Takeuchi Y, Sykes M. 2002. Mechanisms of transplant tolerance induction using costimulatory blockade. Curr Opin Immunol 14: 592-600.

Wu H, Noordmans GA, O’Brien MR, Ma J, Zhao CY, Zhang GY, Kwan TK, Alexander SI, Chadban SJ. 2012. Absence of MyD88 signaling induces donor-specific kidney allograft tolerance. J Am Soc Nephrol 23: 1701-1716.

Yun JJ, Fischbein MP, Whiting D, Irie Y, Fishbein MC, Burdick MD, Belperio J, Strieter RM, Laks H, Berliner JA, et al. 2002. The role of MIG/CXCL9 in cardiac allograft vasculopathy. Am J Pathol 161: 1307-1313. 


\section{$\&_{\mathrm{CSH}}^{\infty} \&$ Cold Spring Harbor

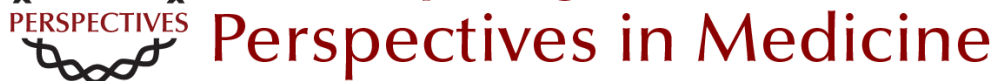

\section{Lessons and Limits of Mouse Models}

Anita S. Chong, Maria-Luisa Alegre, Michelle L. Miller and Robert L. Fairchild

Cold Spring Harb Perspect Med 2013; doi: 10.1101/cshperspect.a015495

Subject Collection Transplantation

Heart Transplantation: Challenges Facing the Field

Makoto Tonsho, Sebastian Michel, Zain Ahmed, et al.

Bioethics of Organ Transplantation Arthur Caplan

Overview of Clinical Lung Transplantation Jonathan C. Yeung and Shaf Keshavjee

Immunological Challenges and Therapies in

Xenotransplantation Marta Vadori and Emanuele Cozzi

Clinical Aspects: Focusing on Key Unique Organ-Specific Issues of Renal Transplantation Sindhu Chandran and Flavio Vincenti

T-Cell Costimulatory Blockade in Organ

Transplantation Jonathan S. Maltzman and Laurence A. Turka

Regulatory T-Cell Therapy in Transplantation: Moving to the Clinic Qizhi Tang and Jeffrey A. Bluestone

Opportunistic Infections--Coming to the Limits of Immunosuppression?

Jay A. Fishman
Overview of the Indications and Contraindications for Liver Transplantation

Stefan Farkas, Christina Hackl and Hans Jürgen Schlitt

Facial and Hand Allotransplantation Bohdan Pomahac, Ryan M. Gobble and Stefan Schneeberger

Induction of Tolerance through Mixed Chimerism David H. Sachs, Tatsuo Kawai and Megan Sykes

Pancreas Transplantation: Solid Organ and Islet Shruti Mittal, Paul Johnson and Peter Friend

Tolerance--Is It Worth It? Erik B. Finger, Terry B. Strom and Arthur J. Matas

Lessons and Limits of Mouse Models Anita S. Chong, Maria-Luisa Alegre, Michelle L. Miller, et al.

Effector Mechanisms of Rejection Aurélie Moreau, Emilie Varey, Ignacio Anegon, et al.

The Innate Immune System and Transplantation Conrad A. Farrar, Jerzy W. Kupiec-Weglinski and Steven H. Sacks

For additional articles in this collection, see http://perspectivesinmedicine.cshlp.org/cgi/collection/ 